\title{
Anatomical Basis for the Selective Block of the Nerve to Quadratus Femoris by Way of Percutaneous Techniques
}

\author{
Bases Anatómicas para el Bloque Selectivo del nervio del músculo \\ cuadrado femoral a Través de Técnicas Percutáneas
}

Mansilla, Alejandra' ${ }^{\text {; Mansilla, Sofía }}{ }^{1}$; Calisto, Joaquín ${ }^{1}$;
Pereira, Crihstian J. ${ }^{\text {; }}$ García, Joaquín ${ }^{2}$ \& Olivera, Eduardo ${ }^{1}$

MANSilla, A.; MANSIlla, S.; CAliStO, J.; PEREIRA, C.; GARCÍA, J. \& OLIVERA, E. Anatomical basis for the selective block of the nerve to quadratus femoris by way of percutaneous techniques. Int. J. Morphol., 38(6):1549-1554, 2020.

SUMMARY: Hip joint chronic pain can severely compromise patients' life quality. Peripheral nerve blocks play an important role as diagnostic and therapeutic procedures. The aim of this work is to study the anatomy of the nerve to quadratus femoris (NQF) in view of the possibility of its percutaneous selective block. Forty-three gluteal cadaveric regions fixed in formaldehyde solution were dissected. The quadratus femoris, the obturator internus and superior and inferior gemellus were freed from their lateral insertion, exposing thus the posterior aspect of the hip joint. The NQF was identified, and the horizontal distance to the posterior edge of the greater trochanter at its upper, middle and lower thirds was registered. The number of the articular branches of the NQF was identified. Likewise, the horizontal distance to the posterior edge of the greater trochanter and the longitudinal distance to the line through the distal end of the posterior edge of the greater trochanter were measured. The distance between the NQF and the greater trochanter posterior edge at upper, middle and lower thirds was $46 \mathrm{~mm}, 41 \mathrm{~mm}$ and $35 \mathrm{~mm}$, respectively. In most cases $(85 \%)$ the NQF presented one or two articular branches. The longitudinal distances between the line through the distal end of the posterior edge of the greater trochanter and the origin of the first, second and third articular branches of the NQF were $14.7 \mathrm{~mm}(-19.4-40), 16.4 \mathrm{~mm}(-9.3-42)$ and $27 \mathrm{~mm}(0-46)$, respectively. The distances to the posterior edge of the greater trochanter were $43.1 \mathrm{~mm}(16.3-66), 37.7 \mathrm{~mm}(6.5-53)$ and $39.8 \mathrm{~mm}(26-52)$, for the first, second and third articular branches, respectively. In conclusion, the articular branches of the nerve to quadratus femoris have a constant and predictable distribution. Our findings allow for generating a coordinate system for the selective block of the NQF by way of percutaneous techniques.

KEY WORDS: Nerve to; Quadratus femoris; hip joint; selective block.

\section{INTRODUCTION}

Chronic hip pain is a common symptom experienced by many people. A prevalence of $7 \%$ to $10 \%$ is estimated in men and women over 45 years old (Okada, 1993; Birrell et al., 2005; Locher et al., 2008).

Osteoarthritis (OA) of the hip and knee represents the primary etiology of walking-related disability. Major symptoms of patients with hip pain include groin, thigh, and trochanteric pain (Rivera et al., 2012). Quality of life is especially affected among patients with hip OA, due to limited ambulation and daily activity (Wu \& Groner, 2007; Rivera et al.).

Conservative management of hip pain includes paracetamol, nonsteroidal anti-inflammatory drugs, narcotics, and physical modalities (Wu \& Groner). Patients who fail to respond to conservative treatment usually undergo surgery. Often, surgery is not an option for patients with multiple comorbidities and conventional drugs either have many side effects or are ineffective (Rivera et al.). In those situations, several methods of neurolysis are available: surgical, chemical, and radiofrequency thermocoagulation (Locher et al.; Rivera et al.; Vanaclocha et al., 2016).

Selective nerve block or transforaminal epidural injection consists of injection of contrast, local analgesics, or other substances around spinal nerves under fluoroscopy (Wu \& Groner). In 1971 demonstrated the value of diagnostic, selective nerve blocks in the preoperative evaluation of

\footnotetext{
${ }^{1}$ Departamento de Anatomía, Facultad de Medicina, Universidad de la República, Montevideo, Uruguay.

${ }^{2}$ Asistente de la Cátedra de Imagenología, Facultad de Medicina, Universidad de la República, Montevideo, Uruguay.
} 
patients with negative or inconclusive imaging studies and clinical findings of nerve root irritation. Since then, nerve blocks have been used to diagnose the source of radicular pain when imaging studies suggested possible compression of several nerve roots (Hoppenstein, 1980; Dooley et al., 1988; Herron, 1989). Several investigators have shown the usefulness of the obturator nerve (ON) block and the femoral nerve (FN) block as a diagnostic and therapeutic tool for patients with hip joint pain but long-term benefits were not observed. The nerve responsible for hip joint pain also can be determined by diagnostic nerve block (HeywangKöbrunner et al., 2001).

Several authors proposed percutaneous radiofrequency techniques (PRT) as an alternative to selective nerve blocking of the articular branches of the ON and FN. Initial results using PRT of articular branches of the obturator and femoral nerves for treatment of hip joint pain are encouraging (Okada; Geurts et al., 2001; Racz \& Ruiz-Lopez, 2006; Wu \& Groner).

Percutaneous denervation of the hip joint was introduced in 1981 and has been applied in patients affected by chronic articular pain. Radiofrequency is a neurolytic technique that uses heat to produce controlled tissue destruction (thermocoagulation). The tip of the electrode is usually placed near the target nerve (Rivera et al.).

Percutaneous pulsed radiofrequency (PRF) or conventional radiofrequency (CRF) of the articular branches of the obturator and femoral nerves is a well-known alternative treatment for hip pain that has been widely reported in literature (Dee, 1969; Wu \& Groner; Locher et al.; Rivera et al.; Yavuz et al., 2013; Vanaclocha et al.).

Based on this, different sensory branches could be treated with this variety of percutaneous techniques based upon the location of the hip pain.

Direct articular branches of adjacent peripheral nerve trunk represent the most important innervation of the hip joint. Also, small accessory articular twigs arising from the nerves within the substance of muscle surrounding the joint form a secondary innervation source (Kawaguchi et al., 2001).

It is known that hip joint pain may be relieved by blocking articular branches of the $\mathrm{ON}$, thigh and trochanteric pain can be relieved by blocking articular branches of the FN, and gluteal pain can be relieved by blocking articular branches of nerves innervating the posterior hip joint: superior and inferior gluteal nerves and sciatic nerve (Gupta et al., 2014).
As we can see, sensory supply of the hip joint is provided by articular branches coming from several nerves. Some authors acknowledged that lack of consistently satisfactory results may have been due to anatomical variations in the sensory nerve supply to the hip (Helmick et al., 2008).

The innervation of the hip joint is complex (Cruveilhier, 1844; Sadovsky, 1933; Gardner, 1948; Birnbaum et al., 1997; Vanaclocha et al.).

The anteromedial sector of the capsule is innervated by branches of the ON (Cruveilhier; Gardner; Dee; Birnbaum et al.). The anterolateral sector of the hip joint capsule is innervated by articular branches of the FN (Sadovsky). Other branches often arise from the nerves to muscle overlying the hip joint (Gardner; Dee). The superolateral sector is innervated by the superior gluteal nerve. (Birnbaum et al.) The lower sector is innervated by the $\mathrm{ON}$ and the inferior gluteal nerve (Birnbaum et al.; Rouvière \& Delmas et al., 2005; Bhatia et al., 2018).

The posteromedial part, posterosuperior and posteroinferior regions of the hip joint capsule are innervated by articular branches of the NQF and often by the sciatic nerve (Cruveilhier; Sadovsky; Gardner; Dee; Birnbaum). This NQF is born from the sacral plexus and emerges from the pelvis through the lower part of the greater sciatic notch. It descends before to the sciatic nerve and to the obturator internus and gemellus muscles that cover it. It provides a nerve fillet to the inferior gemellus muscle and another to the posterior hip joint capsule, and ends at the anterior side of the quadratus femoris muscle (Aung et al., 2001; Rouvière \& Delmas; Bhatia et al.).

Refractive hip pain after selective nerve block and percutaneous radiofrequency techniques over the main nerves trunks of the hip joint can be explained by the accessory innervation of other branches often arise from the nerves to muscles overlying the hip joint (Kawaguchi et al.; Bhatia et al.). The NQF is a clear example of that. Nowadays, the impact of the selective block and other percutaneous techniques of the NQF remain less clear.

As we can see, this nerve has an important role in the innervation of the posterior face of the hip joint, hence the importance of its location for eventual percutaneous procedures in the treatment of posterior gluteal pain (Vanaclocha et al.).

Precise knowledge of the nerve supply of the hip joint is essential to achieve a more effective and long-lasting pain reduction. 
In view of the above, the aim of this work is to perform an anatomical study of the NQF in view of its percutaneous selective block and eventually other percutaneous procedures.

\section{MATERIAL AND METHOD}

Twenty-two formalin-fixed adult cadavers were used. A total of 43 gluteal regions were dissected. All of the dissections were carried out in the laboratories of the Departamento de Anatomía, Facultad de Medicina, Universidad de la República (Montevideo - Uruguay), exclusively by the authors. Previous scars caused by surgery were not observed in the dissected areas of any specimen.

They were processed under the rules of injection and cadaver conservation of the Departamento de Anatomía, Facultad de Medicina, Universidad de la República (Montevideo - Uruguay). The use of cadaveric material was made previous donation, by written and signed informed consent.

An extended incision over the skin and subcutaneous tissues from the iliac crest to the sacral crest, at the level of the lower limb of the intergluteal groove was made. Then completed with a second horizontal incision drawn from the distal end of the anterior to the midpoint of the gluteal fold.

We separated the gluteus maximus and medius muscles from their medial insertions at the sacrum and iliac bone and then pulled back laterally to expose the deep muscular layer.

The quadratus femoris, the obturator internus and superior and inferior gemellus were freed from their lateral insertion at the femur, exposing thus the posterior aspect of the hip joint. The NQF was identified, and a careful dissection of its articular branches was made.

Using calipers, several measurements were made (Fig. 1):

- The NQF was identified, and the horizontal distance to the posterior edge of the greater trochanter at its upper, middle and lower thirds was registered.

-The number of the articular branches of the NQF was identified.

-About each articular branch, the horizontal distance between its origin of the nerve's trunk, and the posterior edge of the greater trochanter was registered. Also the longitudinal distance between its origin and the horizontal line through the distal end of the posterior edge of the greater trochanter (HLGT).

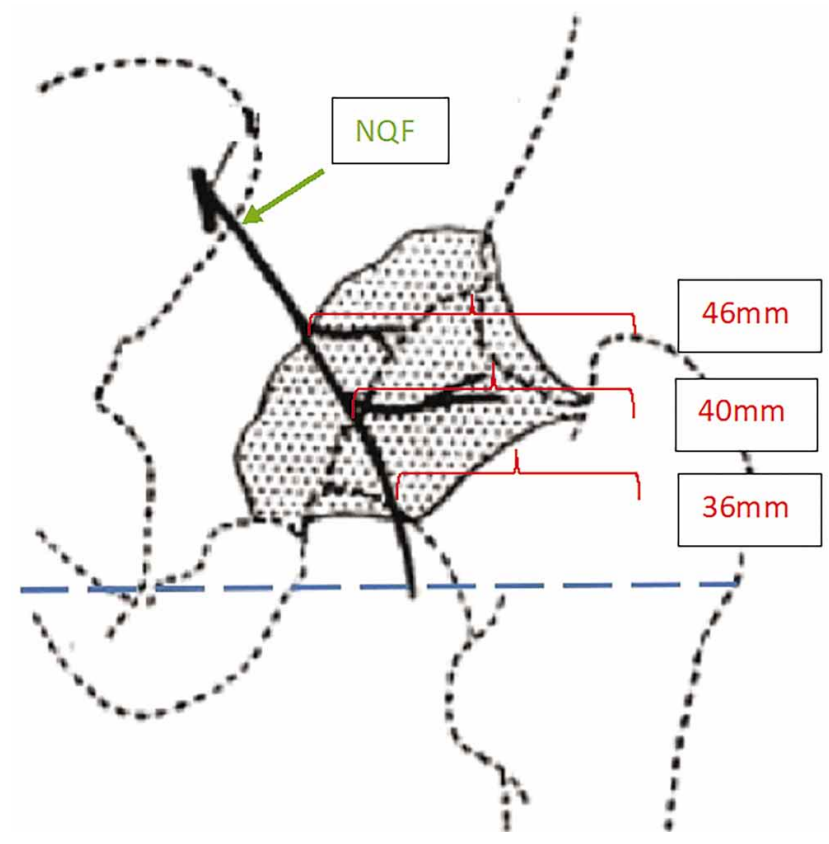

Fig. 1. this figure shows average distances between the NQF and the greater trochanter posterior edge at upper, middle and lower thirds was $46 \mathrm{~mm}, 41 \mathrm{~mm}$ and $35 \mathrm{~mm}$, respectively.

\section{RESULTS}

The presence of NQF articular branches to posterior hip joint capsule were found in all of the cases (100\%). The $\mathrm{NQF}$ presented a downward and lateral oblique descending path along the posterior aspect of the hip joint capsule (Fig. 2).

The average distance between the NQF and the greater trochanter posterior edge at upper, middle and lower thirds was $46 \mathrm{~mm}, 41 \mathrm{~mm}$ and $35 \mathrm{~mm}$, respectively (Fig. 1).

Of the 43 gluteal regions, 87 articular branches to the hip joint were found, each with 1 to 3 articular branches being found. In $39.5 \%$ of cases a single articular branch was found. In $46.5 \%$ of cases they originated 2 articular branches, and only in $14 \%$ of cases originated 3 articular branches. In most cases (85\%) the NQF presented one or two articular branches. An average of 1.6 joint branches was recorded.

The distances between HLGT and the origin of the first, second and third articular branches of the NQF were $14.7 \mathrm{~mm}(-19.4$ - 40), $16.4 \mathrm{~mm}(-9.3-42)$ and $27 \mathrm{~mm}(0-46)$, respectively.

The distances to the posterior edge of the greater trochanter (PEGT) were $43.1 \mathrm{~mm}$ (16.3-66), $37.7 \mathrm{~mm}$ (6.5- 


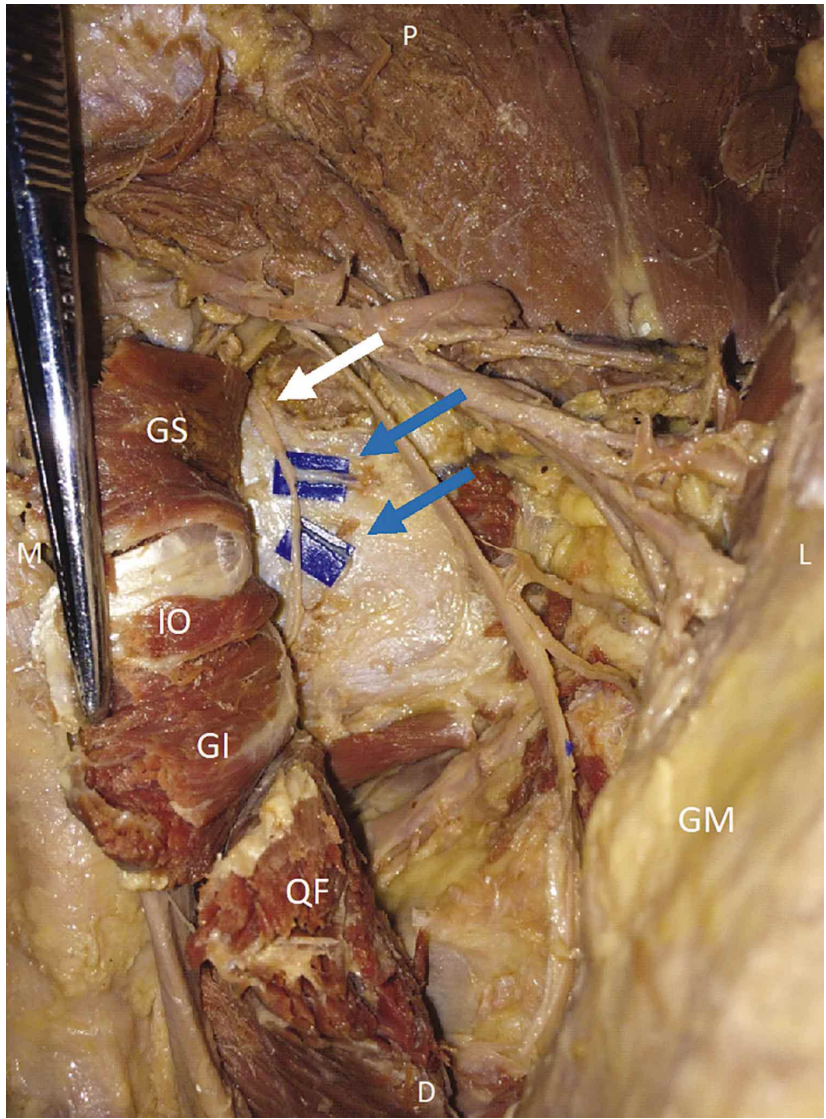

Fig. 2. posterior view of a right gluteal region. The gluteus maximus (GM) was fought medially and the gemellus superior (GS), obturator internus (OI), gemellus inferior (GI) and the quadratus femoris muscles were fought back laterally. We appreciate the posterior face of the hip joint and the nerve to quadratus femoris (NQFwhite arrow) leaning down with 2 articular branches (blue arrows).

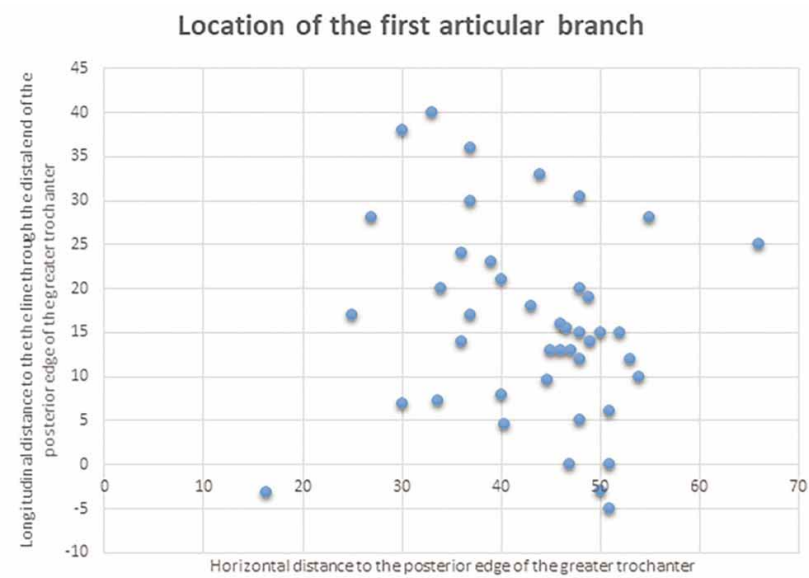

Fig. 3. Graphic of the topography of the first articular branch, in relation to the posterior edge of the major trochanter and the line through the distal end of the posterior edge of the greater trochanter. Includes coordinates of 43 branches. They are on average at a horizontal distance of $43.1 \mathrm{~mm}$ and a longitudinal distance of 14.7 $\mathrm{mm}$.
53) and $39.8 \mathrm{~mm}$ (26-52), for the first, second and third articular branches, respectively.

On average, each branch is found in the following coordinates. The first (upper) articular branch is $43.1 \mathrm{~mm}$ from the PEGT and $14.7 \mathrm{~mm}$ from the HLGT (Fig. 3). The second branch is $37.7 \mathrm{~mm}$ from the PEGT and 16.4 $\mathrm{mm}$ from the HLGT (Fig. 4). Finally, the third branch is $39.8 \mathrm{~mm}$ from the PEGT and $27 \mathrm{~mm}$ from the HLGT (Fig. 5).

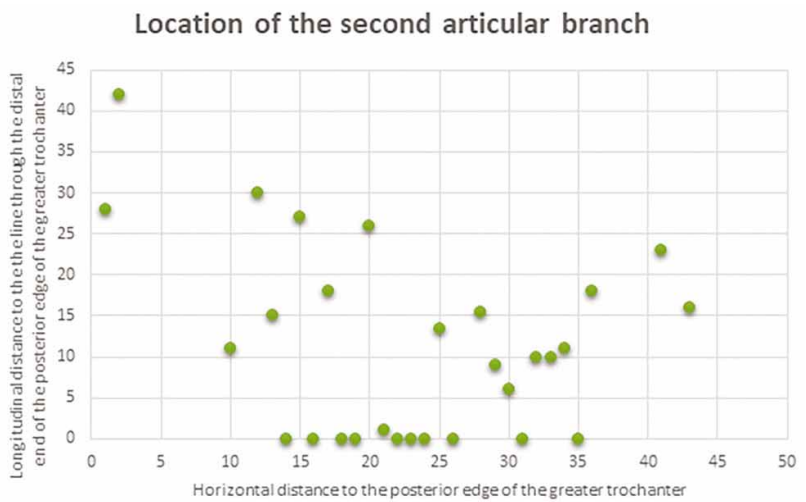

Fig. 4. Graphic of the topography of the second articular branch, in relation to the posterior edge of the greater trochanter and the line through the distal end of the posterior edge of the greater trochanter. Includes coordinates of 20 branches. They are on average at a horizontal distance of $37.8 \mathrm{~mm}$ and at a longitudinal distance of $16.4 \mathrm{~mm}$.

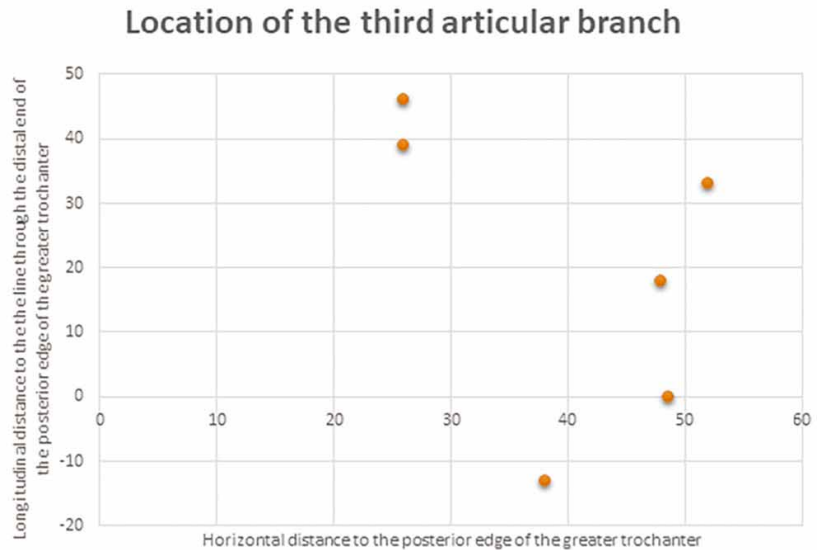

Fig. 5. Graphic of the topography of the third articular branch in relation to the posterior edge of the greater trochanter and the line through the distal end of the posterior edge of the greater trochanter. Includes coordinates of 6 branches. They are on average at a horizontal distance of $39.8 \mathrm{~mm}$ and a longitudinal distance of $27 \mathrm{~mm}$. 


\section{DISCUSION AND CONCLUSION}

Nerve to quadratus femoris (NQF).The NQF was identified at all levels of the posterior edge of the greater trochanter at an average distance of $40 \mathrm{~mm}$. This means that the NQF can be found in the nearest $40 \mathrm{~mm}$ of the PEGT. Being the closest sector to it at the lower third, presenting an average distance of $35 \mathrm{~mm}$.

We found the NQF in all the cases (100\%), giving articular branches to the posterior regions of the hip joint capsule. This is consistent with the literature consulted (Cruveilhier; Sadovsky; Gardner; Dee; Birnbaum et al.; Rouvière \& Delmas; Aung et al.). According with contemporary authors, the posterior articular nerves consist of a varying number of short (5-6 mm long) articular branches of the nerve to the quadratus femoris muscle, and represent the most prolific supply to the hip joint (Dee).

Articular branches: In our study we found between one to three articular branches. An average of 1.6 joint branches was recorded. These results were similar to the consulted bibliography. Birkman et al., found between 1 and 5 branches, Bathia et al., found an average of 3 and Gardner found 1 or 2 in most of the cases.

According to Dee, the superior and middle branches curve upward along the acetabular rim to supply the posterior joint capsule, whereas the inferior branches run directly along the upper margin of the obturator externus where they are distributed to the posteroinferior region of the joint capsule (Dee).

Limitations: Percutaneous procedures have their limitations. The innervation of the hip joint is varied and is supplied by numerous nerve branches. Some authors explain that radiofrequency denervation and other percutaneous techniques of all these nerves are unfeasible (Sadovsky; Locher et al.).

On the other hand, some authors explain that the lack of pain relief in some cases despite a correctly performed procedure, may be explained by the fact that innervation of the hip varies from patient to patient (Okada; Vanaclocha $\mathrm{et} \mathrm{al}$.). In our study we found a small variability between one gluteal region and another.

In conclusion, the articular branches of NQF have a constant and predictable distribution. Our findings allow to generate a coordinate system to survey the NQF path, identifying where its articular branches originate. This is essential to achieve a more effective technique.
Future research on patients undergoing selective nerve blockade of this nerve and other percutaneous techniques could study the long-term usefulness.

Further research based on anatomical topographic mapping of the nerve to quadratus femoris and its articular branches obtained in our work lend themselves to correlation with future clinical trials to try out its diagnostic and therapeutic viability.

MANSILLA,A.; MANSILLA, S.; CALISTO, J.; PEREIRA, C.; GARCÍA, J. \& OLIVERA, E. Bases anatómicas para el bloqueo selectivo del nervio del músculo cuadrado femoral a través de técnicas percutáneas. Int. J. Morphol., 38(6):15491554, 2020.

RESUMEN: El dolor crónico de la articulación coxal puede comprometer severamente la calidad de vida de los pacientes. Los bloqueos nerviosos periféricos juegan un papel importante como procedimientos diagnósticos y terapéuticos. El objetivo de este trabajo es estudiar la anatomía del nervio del músculo cuadrado femoral (NCF) en vista de la posibilidad de su bloqueo selectivo percutáneo. Se utilizaron 22 cadáveres fijados en solución de formaldehído. Fueron disecadas en total 43 regiones glúteas. Los músculos cuadrado femoral, obturador interno y los gemelos superior e inferior fueron liberados de su inserción lateral, exponiendo así la cara posterior de la articulación coxal. Se identificó el NCF y se registró la distancia horizontal al margen posterior del trocánter mayor en sus tercios superior, medio e inferior. Se identificó el número de ramas articulares del NQF. Asimismo, se midió la distancia horizontal al margen posterior del trocánter mayor y la distancia longitudinal a la línea que pasa por el extremo distal del margen posterior del trocánter mayor. La distancia entre el NCF y el margen posterior del trocánter mayor en los tercios superior, medio e inferior fue de $46 \mathrm{~mm}, 41 \mathrm{~mm}$ y $35 \mathrm{~mm}$, respectivamente. En la mayoría de los casos (85\%) el NCF presentó una o dos ramas articulares. Las distancias longitudinales entre la línea que pasa por el extremo distal del margen posterior del trocánter mayor y el origen de la primera, segunda y tercera ramas articulares del NQF fueron 14,7 $\mathrm{mm}(-19,4$ - 40), 16,4 mm (-9,3-42) y $27 \mathrm{~mm}(0-46)$, respectivamente. Las distancias al margen posterior del trocánter mayor fueron 43,1 mm (16,3-66), 37,7 mm (6,5-53) y 39,8 mm (26-52), para la primera, segunda y tercera ramas articulares, respectivamente. En conclusión, las ramas articulares del nervio al cuadrado femoral tienen una distribución constante y predecible. Nuestros hallazgos permiten generar un sistema de coordenadas para el bloqueo selectivo del NCF por medio de técnicas percutáneas.

PALABRAS CLAVE: Nervio; Cuadrado femoral; Articulación coxal; Bloqueo selectivo. 


\section{REFERENCES}

Aung, H. H.; Sakamoto, H.; Akita, K. \& Sato, T. Anatomical study of the obturator internus, gemelli and quadratus femoris muscles with special reference to their innervation. Anat. Rec., 263(1):41-52, 2001.

Bhatia, A.; Hoydonckx, Y.; Peng, P. \& Cohen, S. P. Radiofrequency procedures to relieve chronic hip pain: an evidence-based narrative review. Reg. Anesth. Pain Med., 43(1):72-83, 2018.

Birnbaum, K.; Prescher, A.; Hessler, S. \& Heller, K. D. The sensory innervation of the hip joint--an anatomical study. Surg. Radiol. Anat., 19(6):371-5, 1997.

Birrell, F.; Lunt, M.; Macfarlane, G. \& Silman, A. Association between pain in the hip region and radiographic changes of osteoarthritis: results from a population-based study. Rheumatology (Oxford), 44(3):337-41, 2005 .

Cruveilhier, J. The Anatomy of the Human Body. New York, Harper \& Brothers, 1844.

Dee, R. Structure and function of hip joint innervation. Ann. R. Coll. Surg. Engl., 45(6):357-74, 1969.

Dooley, J. F.; McBroom, R. J.; Taguchi, T. \& Macnab, I. Nerve root infiltration in the diagnosis of radicular pain. Spine (Phila Pa 1976), 13(1):79-83, 1988.

Gardner, E. The innervation of the hip joint. Anat. Rec., 101(3):353-71, 1948.

Geurts, J. W.; van Wijk, R. M.; Stolker, R. J. \& Groen, G. J. Efficacy of radiofrequency procedures for the treatment of spinal pain: a systematic review of randomized clinical trials. Reg. Anesth. Pain Med., 26(5):394400, 2001.

Gupta, G.; Radhakrishna, M.; Etheridge, P.; Besemann, M. \& Finlayson, R. J. Radiofrequency denervation of the hip joint for pain management: case report and literature review. U. S. Army Med. Dep. J., 41-51, 2014.

Helmick, C. G.; Felson, D. T.; Lawrence, R. C.; Gabriel, S.; Hirsch, R.; Kwoh, C. K.; Liang, M. H.; Kremers, H. M.; Mayes, M. D.; Merkel, P. A.; et al. Estimates of the prevalence of arthritis and other rheumatic conditions in the United States. Part I. Arthritis Rheum., 58(1):15-25, 2008 .

Herron, L. D. Selective nerve root block in patient selection for lumbar surgery: surgical results. J. Spinal Disord., 2(2):75-9, 1989.

Heywang-Köbrunner, S. H.; Amaya, B.; Okoniewski, M.; Pickuth, D. \& Spielmann, R. P. CT-guided obturator nerve block for diagnosis and treatment of painful conditions of the hip. Eur. Radiol., 11(6):1047-53, 2001.

Hoppenstein, R. A new approach to the failed, failed back syndrome. Spine, $5(4): 371-9,1980$

Kawaguchi, M.; Hashizume, K.; Iwata, T. \& Furuya, H. Percutaneous radiofrequency lesioning of sensory branches of the obturator and femoral nerves for the treatment of hip joint pain. Reg. Anesth. Pain Med., 26(6):576-81, 2001.

Locher, S.; Burmeister, H.; Böhlen, T.; Eichenberger, U.; Stoupis, C.; Moriggl, B.; Siebenrock, K. \& Curatolo, M. Radiological anatomy of the obturator nerve and its articular branches: basis to develop a method of radiofrequency denervation for hip joint pain. Pain Med, 9(3):291$8,2008$.

Okada, K. New approach to the pain of the hip joint. Pain Res., 8:125-35, 1993.

Racz, G. B. \& Ruiz-Lopez, R. Radiofrequency procedures. Pain Pract., 6(1):46-50, 2006.

Rivera, F.; Mariconda, C. \& Annaratone, G. Percutaneous radiofrequency denervation in patients with contraindications for total hip arthroplasty. Orthopedics, 35(3):e302-5, 2012.

Rouvière, H. \& Delmas, V. Anatomía Humana Descriptiva, Topográfica y Functional. 11th ed. Barcelona, Masson, 2005.

Sadovsky, D. M. Innervation of the capsule of the hip joint. Vestn. Khir., $31: 100-3,1933$
Vanaclocha, V.; Sáiz-Sapena, N. \& Herrera, J. Percutaneous Radiofrequency Denervation in the Treatment of Hip Pain Secondary to Osteoarthritis. EC Orthopaedics, 4(6):657-80, 2016.

$\mathrm{Wu}$, H. \& Groner, J. Pulsed radiofrequency treatment of articular branches of the obturator and femoral nerves for management of hip joint pain. Pain Pract., 7(4):341-4, 2007.

Yavuz, F.; Yasar, E.; Taskaynatanb, M. A.; Goktepe, A. S. \& Tan, A. K. Nerve block of articular branches of the obturator and femoral nerves for the treatment of hip joint pain. J. Back Musculoskelet. Rehabil., 26(1):79-83, 2013.

Corresponding autor:

Dra. Alejandra Mansilla Lizardi.

Francisco Aguilar 818/802 CP 11300

Montevideo

URUGUAY

Email: alejandramansillalizardi@gmail.com

Received: 07-04-2020

Accepted: 14-06-2020 